\title{
Mosque Based Economic Empowerment Model to Overcome Poverty in Indonesia
}

\author{
Muhammad Nizar ${ }^{1}$, Dzikrulloh $^{2}$, Nanang Qosim $^{3}$, Ansori $^{4}$, Riduwan $^{5}$ \\ muhammadnizar@yudharta.ac.id ${ }^{1}$,dzikrulloh@trunojoyo.ac.id ${ }^{2}$, \\ nanangqosim@stai-ypbwi.ac.id ${ }^{3}$, ansori@stai-ypbwi.ac.id ${ }^{4}$, ridwanzainal@stai-ypbwi.ac.id ${ }^{5}$ \\ Universitas Yudharta Pasuruan ${ }^{1}$, Universitas Trunojoyo Madura ${ }^{2}$, Sekolah Tinggi Agama \\ Islam YPBWI Surabaya ${ }^{3,4,5}$
}

\begin{abstract}
Madura has a large number of mosques, but the large number of mosques has not been directly proportional To improve the quality Islamic community on Madura. However, Frequently encountered problems many mosques at the sub-district level to the village that are still not taken care of both in terms of its management and the actual function of the mosque. Therefore, the writer has a solution by utilizing the role of students and the younger generation as creators of ideas about community empowerment through restoring the function of the mosque as the time of the Apostle.
\end{abstract}

Keywords: Economic Empowerment, Mosque-Based Economic Empowerment, Poverty and Solution.

\section{Pendahuluan}

Seiring berkembangnya zaman yang semakin modern, pengembangan fungsi masjid menjadi suatu hal yang sangat urgen, dikarenakan semakin minimnya pemahaman masyarakat terhadap fungsi masjid, rendahnya ilmu pengetahuan dan lemahnya ekonomi [1]. Pengembangan masjid ini tidak hanya dari segi bangunan dan arsitektur, namun dari segi dakwah harus diutamakan khususnya dakwah dengan bentuk pemberdayaan masyarakat [2] misalnya dalam komunitas pesantren [3]. Dakwah pemberdayaan sama dengan gerakan dakwah menuju transformasi sosial, yakni dakwah yang dijabarkan dalam gerakan pembebasan dari eksploitasi, dominasi, penindasan, serta ketidakadilan dalam semua aspeknya [2], [5]. Dari gerakan inilah selanjutnya lahir dan membentuk masyarakat yang memiliki kecanggihan social [6].

Masjid merupakan salah satu tempat berkumpul kaum muslim, terutama untuk ibadah baik mahdoh maupun ghaoiru mahdoh [3]. Pada zaman Rasulullah SAW, masjid mempunyai unsur nilai strategis bagi umat Muslim untuk berembuk segala permasalahan kaum Islam, karena masjid sebagai titik kumpul dari semua aktivtas Rasulullah SAW dan para sahabat. Musyawaroh tentang strategi perang, ibadah, pendidikan, ekonomi dan sosial dilakukan Rasulullan di masjid, bahkan hingga sekarang fungsi masjid sebagaimana yang sudah dikembangkan oleh Rasulullah SAW adalah menjadi rujukan bahkan prototipe bagi umat Muslim untuk menjadikan fungsi masjid seperti pada zaman Rasulullah [4]. Kembali mereview masjid pada zaman Nabi, maka memiliki peran penting dalam pemberdayaan ekonomi umat Islam, perekonomian sekitar masjid berkembang begitu baik [5], [10]. Salah satu fokus kajian ini adalah di pulau Madura, dikarenakan mayoritas penduduk yang ada di pulau Madura beragama Islam dan dibuktikan dengan banyak berdirinya rumah ibadah umat muslim yaitu masjid. 
Madura memiliki jumlah masjid yang cukup banyak, namun diantara masijid-masjid tersebut memiliki manajemen tradisional, yang kurang membantu masyarakat sekitar dalam peningkatan kesejahteraan di Madura. Dilihat dari sejarahnya keindahan, kemewahan masjid bukan hanya pada fisiknya, melainkan sejauh mana masjid tersebut memberdayakan masyarakatnya. Namun permasalahan-permasalahan yang sering di hadapi diantaranya masih banyak masjid ditingkat kecamatan hingga desa yang masih belum terurus baik dalam hal pengelolaannya maupun fungsi masjid sesungguhnya, minimnya pemasukan dan programprogram pemberdayaan di masjid-masjid tersebut, hingga berdirinya amal-amal dipinggir jalanan Madura khususnya di Daerah Bangkalan, kurang tersentuhnya masjid-masjid kecil disekitar, oleh para donator, kurangnya pengetahuan pengelola masjid dalam upaya memaksimalkan fungsi masjid.

Agar lebih memudahkan penerapan perogram maka diambil sebuah studi kasus di daerah Bangkalan yakni di Masjid Martajazah (Saichona Muhammad Kholil). Daerah tersebut merupakan sasaran program ini karena tempat yang strategis dengan model masjid yang sekaligus sebagai tempat wisata. Masjid tersebut sudah berdaya dan menghidupkan ekonomi masyarakat, akan tetapi didaerah sekitarnya masjid yang lainnya masih banyak masjid-masjid yang masih belum terurus, minimnya pemasukan dan program-program pemberdayaan di masjid-masjid seperti permasalahan yang telah digambarkan. Oleh karena itu, penulis memiliki solusi dengan cara memanfaatkan peran mahasiswa dan generasi muda sebagai pencipta gagasan mengenai pemberdayaan masyarakat melalui mengembalikan fungsi masjid seperti zaman Rasulullah ditambah dengan model pemasaran menggunakan teknologi [11]. Melalui masjid para generasi muda menyumbangkan inovasinya, dan berperan lebih terhadap masjid [6].

Mengingat pemuda adalah generasi penerus yang seharusnya membawa kebaikan, sehingga dengan adanya solusi yang ditawarkan dapat menyelesaikan masalah-masalah yang ada di mashyarakat tersebut [7]. Penulis juga melibatkan pihak-pihak terkait dalam menjalankan program ini, seperti pihak pengurus masjid, tokoh masyarakat dan bahkan dengan pemerintah setempat [8]. Dengan hal ini harapan kedepannya adalah dari masjid oleh masjid dan untuk masjid dengan tujuan pemberdayaan ekonomi sekitar masjid. Oleh karena itu peneliti mengambil tema Model pemberdayaan ekonomi berbasis masjid melalui community of empowered mosque groups guna mengatasi kemiskinan di Indonesia.

Berangkat dari latar belakang, maka rumusan masalah dalam penelitian ini adalah bagaimana model pemberdayaan ekonomi berbasis masjid melalui community of empowered mosque groups guna mengatasi kemiskinan di Indonesia. Bagaimana harapan kedepan diterapkannya Model Pemberdayaan Ekonomi Berbasis Masjid Melalui Community of Empowered Mosque Groups Guna Mengatasi Kemiskinan di Indonesia.

\section{Kajian Teori}

\section{a. Pemberdayaan Ekonomi}

Teori pemberdayaan datang akibat reaksi dari alam bawah sadar manusia, untuk mampu bangkit, dan keluar dari zona nyaman sudah ada sebelumnya dan sudah ada sebelumnya kemudian berkembang di suatu Negara [15], [16]. Konsep empowerment (peberdayaan) muncul pada tahun 1970-an dan terus mengalami perkembangan sepanjang dekade 1980-an sampai 1990-an [9]. Kemunculan konsep pemberdayaan bersamaan dengan aliran-aliran fenomenologi, eksistensialisme, dan personalisme. Kemudian masuk gelombang pemikiran 
freudianisme, neo-marxisme, termasuk aliran strukuralisme dan sosiologi kritik sekolah Frankurt dan civil society [18].

\section{b. Pemberdayaan Ekonomi Berbasis Masjid}

Pemberdayaan ekonomi yang dilakukan di masjid atau istilah sekarang berbasis masjid merupakan sebuah konsep yang mengaktualisasikan fungsi dan peran masjid. Beberapa tahapan yang umumnya dilakukan dalam upaya pemberdayaan masyarakat adalah sebagai berikut: pertama, menciptakan iklim atau suasana yang mampu membangkitkan potensi masyarakat sekitar untuk berkembang. Pada tataran ini, intinya adalah edukasi, yang memuat bahwa setiap masyarakat memiliki potensi yang bisa dikembangkan, sehingga dapar meningkatkan SDM yang dapat mensejahterakan lingkungan sekitar. Kedua, berusaha memperkuat potensi yang dimiliki masyarakat. Pada tahapan tersebut, dibutuhkan beberapa langkah yang positif. Langkah positif dimaksud mencakup beberapa langkah nyata, dan menyangkut penyediaan berbagai input, dan pembukaan akses ke berbagai peluang yang dapat menjadikan masyarakat memiliki berdaya saing. selanjutnya, memberdayakan mengandung arti melindungi. Dalam tahapan pemberdayaan, harus dicegah, yang lemah harus dibantu, agar memiliki dan mampu bersaing dengan yang kuat. [10].

\section{c. Kemiskinan dan Solusinya}

Sekarang ini kemiskinan telah menjadi permasalahan pembangunan yang bersifat relativ. Kemiskinan mampu dengan mudah ditandai dan ditentukan dengan kondisi latarbelakangnya, ketidakmampuan bahkan ketidakberdayaan dari sudut ekonomi, serta sangat banyaknya jumlah masyarakat yang tidak bekerja, yang kemudian menjadi pemicu ketertimpangan kesejahteraan dan kesenjangan antar penduduk. Kemiskinan adalah kondisi kehidupan seseorang dengan standar kehidupan yang kurang layak. Kemiskinan juga dapat didefinisikan kondisi seseorang di mana tidak mampu memenuhi kebutuhan primer sebagai manusia, diantaranya adalah makanan dan pakaian. Ada beberapa konsep yang sudah banyak dikenal yaitu absolutely poor (kemiskinan absolute) dan kemiskinan relatif. Absolutely poor dapat dibagi ke dalam dua bagian yaitu kemiskinan untuk basic needs dan kemiskinan untuk dapat memenuhi kebutuhan yang hampir lebih tinggi [11].

\section{Metodologi}

Penelutian ini menggunakan pendekatan kualitatif diskriptif, Menurut Meleong definisi penelitian kualitatif yaitu research yang menghasilkan prosedur analisis yang tidak menggunakan data statistik atau matematik. Tujuan research kualitatif adalah mendeskripsikan dan menganalisis peristiwa, fenomena, aktifitas, sikap, sosial, persepsi maupun pemikiran seseorang baik individu maupun kelompol, [12]. Lokasi Penelitian yaitu Masjid Martajasah Syaichona Kholil Desa Martajasah Kecamatan Bangkalan Kabupaten Bangkalan Madura. Sumber data diperoleh dari dua element yaitu primer dan data sekunder [13]. Sedangkan pengumpulan memakai teknik wawancara semi struktural dan teknik dokumentasi. [14]. Teknis analisis data memakai aktifitas data kualitatif, secara umum dapat diklasifikasikan dengan pengumpulan bahan untuk penulisan penelitian, penyusunan penelitian, dan memberikan kesimpulan [15]. 


\section{Temuan dan Pembahasan}

Berdasarkan gambar bagan di atas program-program dan alur koordinasi yang akan dijalankan sebagai berikut:

1. Sosialisasi program mahasiswa sebagai pengusul program nantinya akan berkolaborasi dengan masyarakat untuk mensosialisasikan program. Pertama akan mensosialisasikan mengenai fungsi masjid pada masa Rasulullah, pemberdyaan ekonomi dan perencanaan pembuatan komunitas masjid berdaya melalui koordinator disetiap masjid [16], sehingga masyarakat menyadari pentingnya zakat, infak, sadaqah dan wakaf dan menjadi sumber pemasukan bagi masjid sekaligus menjadi instrumen pemberdayaan masyarakat, dari masyarakat juga nantinya kembali pada masyarakat.

2. Pembentukan Community of Empowered Mosque Groups melalui koordinator setiap masjid setelah proses sosialisasi program.

3. Program pemberdayaan, diawali dengan sosialisasi tahap dua mengenai ZISWAF sehingga masyarakat lebih antusias untuk ikut berkontribusi. Sinergitas anatara semua pihak dalam menjalankan program-program sehingga terciptanya sistem yang baik dan output sesuai harapan.

\section{Kesimpulan}

Kesimpulan dari peneletian ini bahwa masjid tidak hanya berhubungan dengan ibadah mahdlah, namun juga mengenai ghairu mahdhah, seperti pendidikan, kebudayaan, dan ekonomi. Hal ini sudah ditunjukkan pada saat Rasulullah memimpin, kebanyakan di era sekarang masjid yang ada masih belum sesuai dengan fungsi aslinya sehingga terjadi ketidak sesuaian. Sehingga dengan adanya penelitian ini beserta saran dapat meningkatkan dan meningkatkan fungsi masjid dan perekonomian umat. Model pemberdayaan ekonomi melalui masjid sudah banyak dilakukan tetapi memberdayakan masyarakat melalui komunitas masjid merupakan gerakan awal untuk menuju berdaya. Dalam program tersebut juga disusun secara sistematis, melalui struktur komunitas, program yang dicanangkan serta sinergitas dari pihakpihak terkait, sehingga Community of Empowered Mosque Groups bisa dilajalankan dan bisa menentukan pencapaiannya melalui evaluasi.

\section{References}

[1] M. M. Alwi, "Optimalisasi Fungsi Masjid Dalam Pemberdayaan Ekonomi Masyarakat,” AlTatwir, 2015.

[2] N. Qosim, "Menjajaki Potensi Islamisasi Ilmu Ekonomi," EL-BANAT J. Pemikir. dan Pendidik. Islam, vol. 6, no. 2, pp. 129-142, 2016.

[3] A. A. Razak, M. Yahya, M. Hussin, and F. Muhammad, "Economic Significance of Mosque Institution in Perak State, Malaysia," Kyoto Bull. Islam. Area Stud., 2014.

[4] fikri abdul Absari, "Strategi Masjid Dalam Pemberdayaan Ekonomi Umat," Strateg. MASJID DALAM Pemberdaya. Ekon. UMAT (Studi Pada Masjid Raya Pondok Indah dan Masjid Jami Bintaro Jaya), 2011.

[5] A. Muslim, R. Karsidi, M. Wijaya, and H. Joebagio, "A Mosque-Based Economic Empowerment Model for Urban Poor Community," Int. J. Soc. Sci. Res., 2014.

[6] A. Basit, "STRATEGI PENGEMBANGAN MASJID BAGI GENERASI MUDA," KOMUNIKA J. Dakwah dan Komun., 1970.

[7] S. H. Hamzah, K. Kunci, : Perkembangan, P. D. Orla, and R. Orba, "PERKEMBANGAN PESANTREN DI INDONESIA (Era Orde Lama, Orde Baru, Reformasi),”Syamil, 2014. 
[8] M. Nizar, "Prinsip Kejujuran Dalam Perdagangan Versi Islam,” J. Istiqro, 2018.

[9] I. Ruslan, "Pemberdayaan Ekonomi Masyarakat Berbasis Masjid di Pontianak," J. Khatulistiwa - J. Islam. Stud., 2012.

[10] C. Nurjamilah, "Pemberdayaan Masyarakat Berbasis Masjid dalam Perspektif Dakwah Nabi saw.," J. Islam. Stud. Humanit., 2017.

[11] M. Imron, "Kemiskinan dalam Masyarakat Nelayan,” J. Masy. dan Budaya, 2003.

[12] Sugiyono, "Penelitian Kuantitatif," Pemaparan Metod. Kuantitatif, 2017.

[13] D. M. A. Lexy J. Moleong, "Metodologi Penelitian Kualitatif (Edisi Revisi)," PT. Remaja Rosda Karya, 2019.

[14] S. R. Pupu, "Penelitian Kualitatif," Journal Equilibrium. 2009.

[15] A. Rijali, "ANALISIS DATA KUALITATIF," Alhadharah J. Ilmu Dakwah, 2019.

[16] P. Campoy-Munoz, M. Alejandro Cardenete, and M. Carmen Delgado, "Assessing the economic impact of a cultural heritage site using social accounting matrices: The case of the Mosque-Cathedral of Cordoba," Tour. Econ., 2017. 